Review

\title{
Non-Saccharomyces Yeasts and Organic Wines Fermentation: Implications on Human Health
}

\author{
Alice Vilela $\mathbb{D}$ \\ CQ-VR, Chemistry Research Centre, School of Life Sciences and Environment, Dep. of Biology and Environment, \\ University of Trás-os-Montes and Alto Douro (UTAD), 5000-801 Vila Real, Portugal; avimoura@utad.pt
}

Received: 12 May 2020; Accepted: 21 May 2020; Published: 25 May 2020

check for updates

\begin{abstract}
A relevant trend in winemaking is to reduce the use of chemical compounds in both the vineyard and winery. In organic productions, synthetic chemical fertilizers, pesticides, and genetically modified organisms must be avoided, aiming to achieve the production of a "safer wine". Safety represents a big threat all over the world, being one of the most important goals to be achieved in both Western society and developing countries. An occurrence in wine safety results in the recovery of a broad variety of harmful compounds for human health such as amines, carbamate, and mycotoxins. The perceived increase in sensory complexity and superiority of successful uninoculated wine fermentations, as well as a thrust from consumers looking for a more "natural" or "organic" wine, produced with fewer additives, and perceived health attributes has led to more investigations into the use of non-Saccharomyces yeasts in winemaking, namely in organic wines. However, the use of copper and sulfur-based molecules as an alternative to chemical pesticides, in organic vineyards, seems to affect the composition of grape microbiota; high copper residues can be present in grape must and wine. This review aims to provide an overview of organic wine safety, when using indigenous and/or non-Saccharomyces yeasts to perform fermentation, with a special focus on some metabolites of microbial origin, namely, ochratoxin A (OTA) and other mycotoxins, biogenic amines (BAs), and ethyl carbamate (EC). These health hazards present an increased awareness of the effects on health and well-being by wine consumers, who also enjoy wines where terroir is perceived and is a characteristic of a given geographical area. In this regard, vineyard yeast biota, namely non-Saccharomyces wine-yeasts, can strongly contribute to the uniqueness of the wines derived from each specific region.
\end{abstract}

Keywords: ochratoxin A (OTA); mycotoxins; biogenic amines (BAs); ethyl carbamate (EC); organic wines; non-Saccharomyces

\section{General Introduction}

As defined at the European level by the European Council Regulations on organic production, organic grapes come from vineyards grown under organic farming methods. Indeed, the International Federation of Organic Agriculture Movement (IFOAM) defines organic viticulture and winemaking as a "holistic production management system which promotes and enhances agro-ecosystem health, including biodiversity, biological cycles, and soil biological activity. It emphasizes the use of management practices in preference to the use of off-farm inputs, considering that regional conditions require locally adapted systems" [1,2]. As of August 2012, organic wines can be labeled "organic" with the EU organic logo. This means the wine can now be properly recognized as an organic product [3]. However, and because the laws regulating organic wine production vary worldwide, the definition "organic wine" does not have the same meaning in all places. Usually, the most important purpose is to avoid synthetic chemical fertilizers and pesticides and genetically modified organisms. In many countries such as the USA, Canada, and Australia, this category of wines has been regulated from 
2000, while in Europe, organic wines have been regulated by law since 2012 (EC Regulation No. 203/2012 [4]). Nowadays, many countries, despite having some different regulations, allow organic wine agronomists and winemakers to use the term "organic wine" along with the organic logo on their label after certification (Table 1). In Europe, the organic wines are certified by private structures authorized by a public authority. This regulation allows consumers to distinguish organic wines from conventional wines $[5,6]$.

Table 1. Difference about regulation in terms of maximum use of $\mathrm{SO}_{2}(\mathrm{mg} / \mathrm{L})$ allowed during vinification, the percentage of the organic vineyard in the country (data from 2015 to 2016), and the organic wine label used on their local market [7].

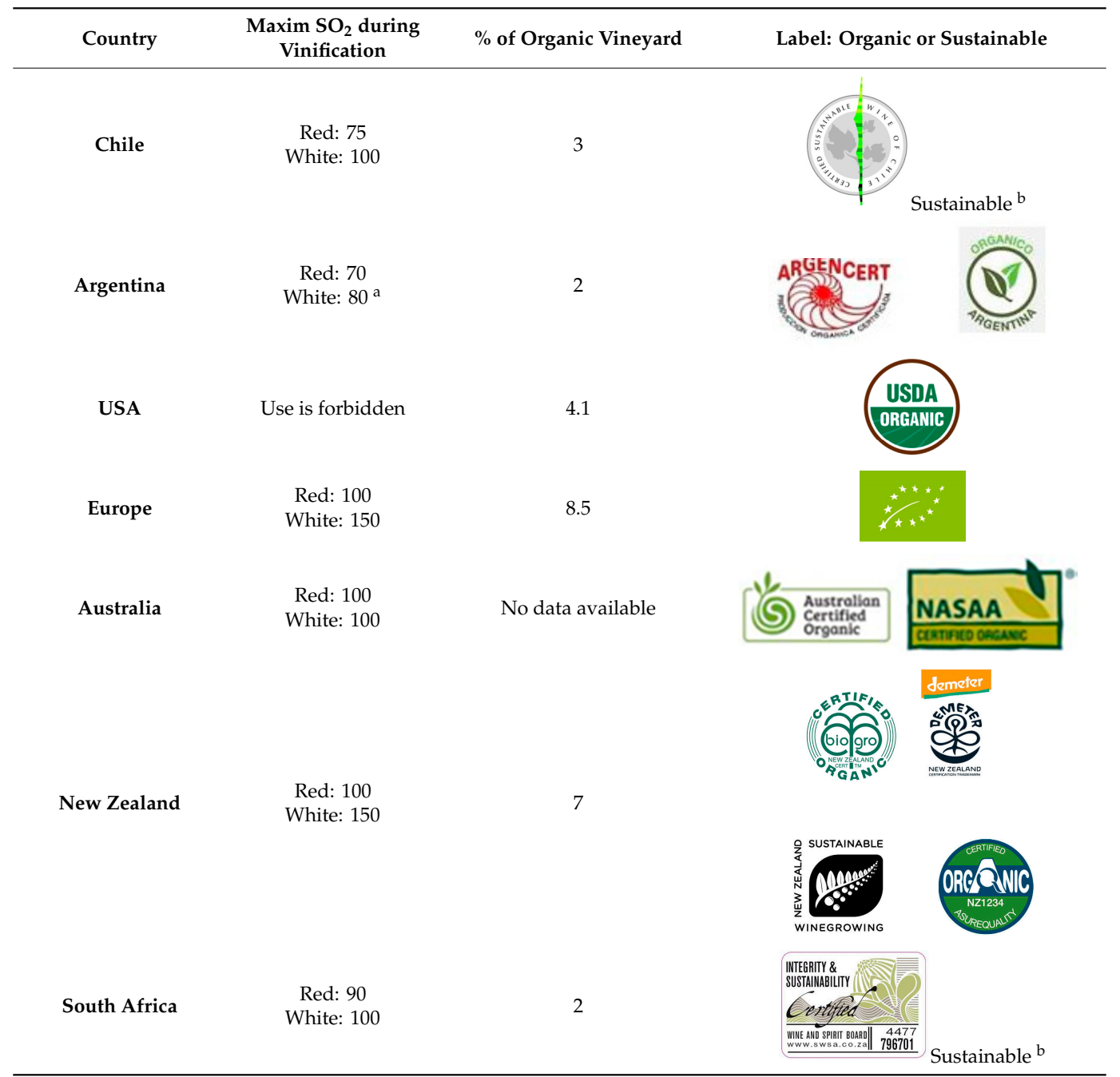

${ }^{a} 100 \mathrm{mg} / \mathrm{L}$ in aged wines; ${ }^{\mathrm{b}}$ no specific label for organic wines.

As Europe vineyards constituted over $80 \%$ of the world's total organic grape growing area in 2014 [6], the European Union (EU) regulations on "organic wine" were an important measure for the global organic wine market. Thus, since the organic certification and standards defined in the EU regulation, it is possible to define exclusive standards with additional detailed production rules. Private standards are appreciated by many winemakers and many consumers as indications of quality wine that authentically express terroir, and that aim to strengthen the subsequent aspects of viticulture and enology: (i) biodiversity in grape production; (ii) attention to soil fertility and soil life; (iii) alternative approaches to pests and diseases; (iv) sustainability of grape production and wine processing and storage; (v) quality and source of wine ingredients, including further limitations on enrichment and requirements for ingredients to be fully organic; (vi) quality of yeasts, including wild 
yeasts and spontaneous fermentation; (vii) further limitations on additives and further reduction or total ban of sulfites; (viii) further limitations on processing techniques; and (ix) requirements or limitations on tools and equipment [3]. Undeniably, the yeasts present on grape berries from organic vineyards have an inimitable composition and may deliver distinct regional characteristics to this kind of wine [8].

Moreover, according to European regulations, organic wine must be made of organic ingredients. Thus, additional rules for oenological practices, processes, treatments, and substances such as additives and processing aids must be considered. Many practices and substances used in conventional production are unsuitable for organic wine production (Table 2), and there are specific restrictions and limitations, requiring that organic products and substances be used if they are available.

Table 2. List of substances forbidden in organic wines production [3].

\begin{tabular}{cc}
\hline Substance & Application \\
\hline $\begin{array}{c}\text { Sorbic acid and sorbates } \\
\text { Lysozyme } \\
\text { Chitosan }\end{array}$ & Microbiological stabilization \\
\hline L-malic acid, D, L-malic acid & Acidification \\
\hline Ammonium bisulfite & Protection of harvesting \\
\hline Ammonium sulfate & Management of alcoholic fermentation \\
\hline $\begin{array}{c}\text { Chitin-glucan } \\
\text { Chitosan } \\
\text { Calcium alginate } \\
\text { Co-polymer of vinylimidazole and vinylpyrrolidone (PVI-PVP) }\end{array}$ & Tartrate/Color stabilization \\
\hline $\begin{array}{c}\text { Carboxymethylcellulose (CMC) } \\
\text { Yeast mannoproteins }\end{array}$ & Correction of color \\
\hline Polyvinylpolypyrrolidone (PVPP) & Glucan elimination \\
\hline Beta-glucanase enzymes & Treatment, elimination of ochratoxin A and urea \\
\hline Chitin-glucan \\
Chitosan \\
Calcium phytate \\
Potassium ferrocyanide
\end{tabular}

However, despite all these wine private standards, wine safety, for winemakers and consumers, relies upon a complex equilibrium from good winemaking practices, quality of grapes, fermentation, and post-fermentation events. An occurrence in wine safety results in the recuperation of a broad variety of harmful compounds for human health such as amines, carbamate, methanol, mycotoxins, and other dangerous compounds [9].

The perceived increase in sensory complexity and superiority of successful uninoculated wine fermentations, as well as a thrust from consumers looking for a more "natural" or "organic" wine, produced with fewer additives and perceived health attributes, has led to more investigations into the uses of non-Saccharomyces yeasts in wine [10-14]. Research in this field aims to understand how to use only the positive contributions of non-Saccharomyces yeasts while avoiding negative contributions.

This review aims to provide an overview of organic wine safety, when using indigenous and/or inoculated non-Saccharomyces yeasts to perform fermentation, with a special focus on some metabolites of microbial origin, namely, ochratoxin A (OTA) and other mycotoxins, biogenic amines (BAs), and ethyl carbamate (EC). These health hazards present an increased awareness of the effects on health and well-being by wine consumers.

\section{Wine Contamination by Ochratoxin A (OTA) and Other Mycotoxins}

Human health issues and scientific attention are focused mainly on carcinogenic/toxic mycotoxins [15,16]. More than 300 mycotoxins have been identified, and they are produced by filamentous fungi, mainly Aspergillus spp, Fusarium spp., and Penicillium spp. [17]. 
OTA is produced from fungi, namely Aspergillus spp. and Penicillium spp., and derives from 3,4-dihydrocumarin linked to an amide bond with an amino group of L- $\beta$-phenylalanine $[18,19]$, and it can appear in grapes (pre-harvest) and/or during pre-fermentation [20,21]. Its presence in wines is mainly found in red wine, followed by rosé and white wines [22,23].

Ochratoxin A is classified by the International Agency for Research on Cancer (IARC) [24] in group 2B (possible human carcinogen), so it is a great threat for humans. It accumulates in several tissues in the body, with the kidneys being its main target, causing Balkan endemic nephropathy (BEN), chronic interstitial nephritis, and karyomegalic interstitial nephritis [9]. The presence of OTA in blood from healthy humans confirms continuous and widespread exposure, thus the Scientific Panel on Contaminants in the Food Chain from the European Food Safety Authority [25] set OTA tolerable weekly intake (TWI) to $120 \mathrm{ng} / \mathrm{kg}$ body weight [9]. OTA levels in wines depend on various factors such as weather and vineyard location, the period of harvest, pesticide treatments, wine fermentation, and duration of grape maceration [9]. The European Union allows a maximum limit for OTA in the wine of $2 \mathrm{ng} / \mathrm{g}$ [23].

The wines/musts decontamination of OTA has been revised by Quintela et al. [26] and, for conventional wines, physical, chemical, or biological methods can be applied. For organic wines, owing to the restrictions imposed by IFAOM, most of the chemical treatments cannot be used once the chemical products recommended for conventional wines (chitin and chitosan, urease, polyvinylpolypyrrolidone (PVPP) [23]) are forbidden for this kind of wine.

A possible way for wine decontamination could be the bioremediation $[21,26]$ through toxin degradation and adsorption. Several enzymes may be involved in the microbiological degradation of OTA, but not much information is available and only a few have been characterized, including the pancreatic enzyme carboxypeptidase A (CPA) (EC 3.4.17.1) from bovine, the first protease reported to be able to hydrolyze OTA [27]. Toxin degradation can be performed by the bacteria Pediococcus parvulus [28], the bacteria Acinetobacter calcoaceticus [29], and the soil bacteria Cupriavidus basilensis [19]. These microorganisms hydrolyze the OTA amide bond and produce ochratoxin $\alpha(\mathrm{OT} \alpha)$, a non-toxic compound (Figure 1). This pathway is promising; however, the production of OT $\alpha$ could also be a threat, because the implication of the accumulation of this compound in the body is yet unclear.

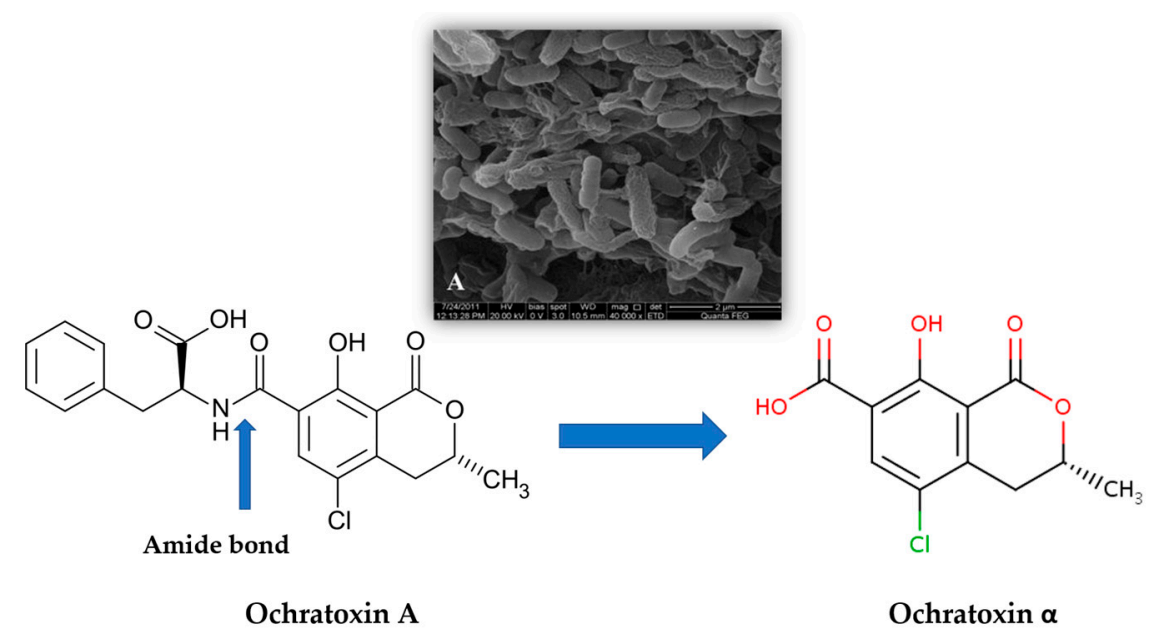

Figure 1. Proposed cleavage of ochratoxin A by Cupriavidus basilensis ŐR16. The amide bond hydrolysis forming ochratoxin $\alpha$ as the major degradation product [19]. A-Scanning electron microscope (SEM) micrograph, magnification of 40,000 of a Cupriavidus basilensis biofilm [30].

A second way for wine decontamination is OTA adsorption on the yeast cell wall during fermentation. For oenological strains, the parietal adsorption activity is a new selection feature that is attractive because it can enhance wine safety and quality [31]. Several authors proposed the yeasts as adsorbing tools under both in vitro and in vivo conditions [21,32,33]. Several studies have also 
reported the interaction of yeast cells with a diversity of wine compounds, from coloring pigments such as anthocyanins [34] to sulfur compounds [35] or detrimental components such as octanoic and decanoic acids [36], pesticides [37], geosmin [38], and 4-ethylphenol [39].

The yeast parietal adsorption activity is different from yeast to yeast, depending on the structural characteristics and chemical composition of the outermost layer of the cell wall. This layer is made up of mannoproteins, which represent $25-50 \%$ of the entire cell wall [40]. Parietal mannoproteins relate to an inner matrix of amorphous $\beta-1,3$ glucan and are partly released in wine (Figure 2).
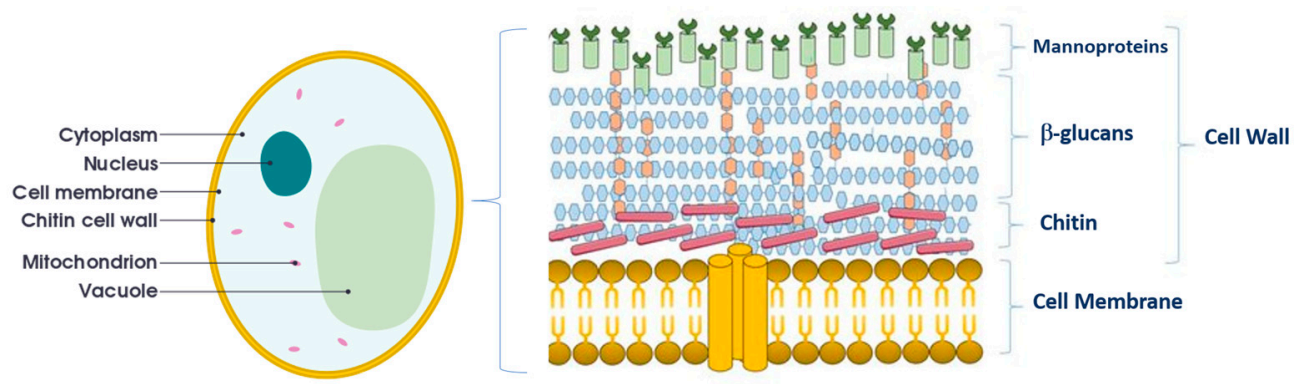

Figure 2. Constitution of yeast and yeast cell wall. Yeast $\beta$-glucans form long chains of a $\beta-(1 \rightarrow 3)$

linked glucan backbone with $\beta-(1 \rightarrow 6)$ linked glucose side branches Adapted from Anwar et al. [40].

Total charge, charge distribution, and accessible surface area of mannoproteins are the most important features determining adsorption, and these features differ among strains [41]. Mannoproteins from Schizosaccharomyces pombe generally contain $\beta$-1,3-linked pyruvylated galactose residues [42], whereas mannoproteins from Pichia pastoris mainly contain mannose phosphate diesters [43]. The percentage of acidic oligosaccharides, containing mannosyl phosphate, varies from strain to strain in Saccharomyces, Kloeckera brevis, and Candida albicans, whereas the oligosaccharides of S. pombe and Kluyveromyces lactis do not contain mannosyl phosphate [44]. The presence of acidic oligosaccharides and negative charges modifies the electrostatic and ionic interactions between the yeast's cell wall and wine components. Moreover, wine yeasts may exhibit a different ratio of neutral/acidic oligosaccharides in mannoproteins. This oenological effect can help us to choose a specific selection of wine yeasts, even though the extent of mannosyl phosphorylation also depends on culture conditions such as the media and cultivation period [44].

Parietal mannoproteins, which perform various oenological functions [31], regarding their adsorption activity, adsorb ochratoxin A from grape must and wine. Numerous investigators studied the removal of OTA by yeasts during fermentation [21,33,45,46]. Truly, ochratoxin A removal depends on yeast macromolecules, such as mannoproteins, and corresponds to a spontaneous adsorption mechanism [47,48] where mannoproteins act like a sponge, removing ochratoxin A [49]. Moreover, this phenomenon can be strongly affected by some factors that also affect the fermentation process, like $\mathrm{pH}$, temperature, sugar, and nitrogen supplementation [50]. Furthermore, this phenomenon is somewhat reversible, as the toxin can be released back into the wine [50]. Yeast immobilization into alginate beads is an interesting technique, aiming to promote a better absorptivity. According to Farbo et al. [51], immobilized yeasts were able to remove $80 \%$ of OTA in $48 \mathrm{~h}$ and toxin release by beads could be better controlled than in free cells, and, additionally, the entrapped cells could be re-usable.

Yeast mycotoxin adsorption, considered to be performed by the surface of cell walls, varies with the yeast species as they are diverse in cell wall composition, varying in adsorption capacity [52]. Many yeast species can absorb mycotoxins, including S. cerevisiae, Candida tropicalis, Pichia pastoris, and Phaffia rhodozyma $[45,53,54]$.

Yeast cells having integrated cell walls are generally more effective in their mycotoxin adsorption capacity than other yeast cells, indicating that toxin adsorption requires the structural integrity of the yeast cell wall [55]. The interaction mechanism studies of mycotoxins and yeast cells focused 
on the toxin adsorption capability associated with cell wall physical structure and the morphology, chemical components, and complicated interactions between structure and these components have been studied. Armando et al. [56] suggested that the cells with the greatest cell wall content seem to present the highest mycotoxin removal percentage, in contrast with those with less content. Luo et al. [57] investigated patulin adsorption capabilities of four yeast strains, among them were two non-Saccharomyces, Candida tropicalis $\mathrm{N}-10$ and Pichia anomala B-2p, with different cell wall thicknesses and cell morphologies. The mycotoxin patulin adsorption capability decreased or disappeared when the cell wall three-dimensional network was damaged or removed.

\section{Organic Wines Contamination with Biogenic Amines}

Biogenic amines (BAs) are low-molecular-weight organic molecules originating in fermented foods from the microbial catabolism of the corresponding amino acids. Wine BA includes putrescine (from arginine and ornithine), cadaverine (from lysine), tyramine (from tyrosine), histamine (from histidine), and tryptamine (from tryptophane) [9]; Figure 3. The production of BAs is a strategy to obtain metabolic advantages to face certain stress conditions [58].

BAs are present as salts, but, at the mouth $\mathrm{pH}$, they are partly in free form, becoming reactive with other compounds responsible for the aroma of the wine, thus they can be responsible for sensory changes like loss of varietal character and the appearance of musty smell and flavor $[59,60]$.

A

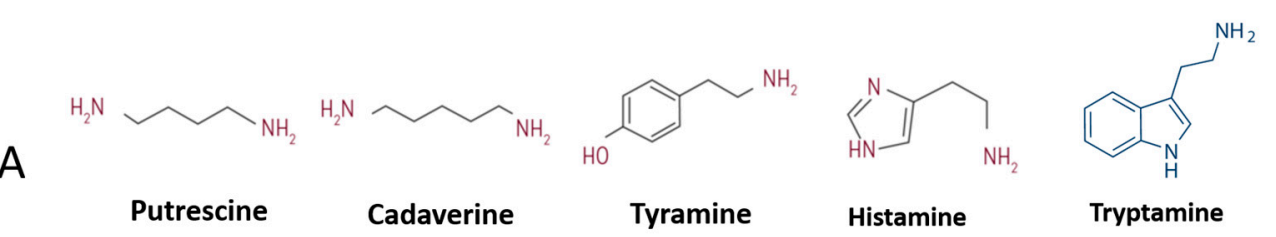

\section{B}
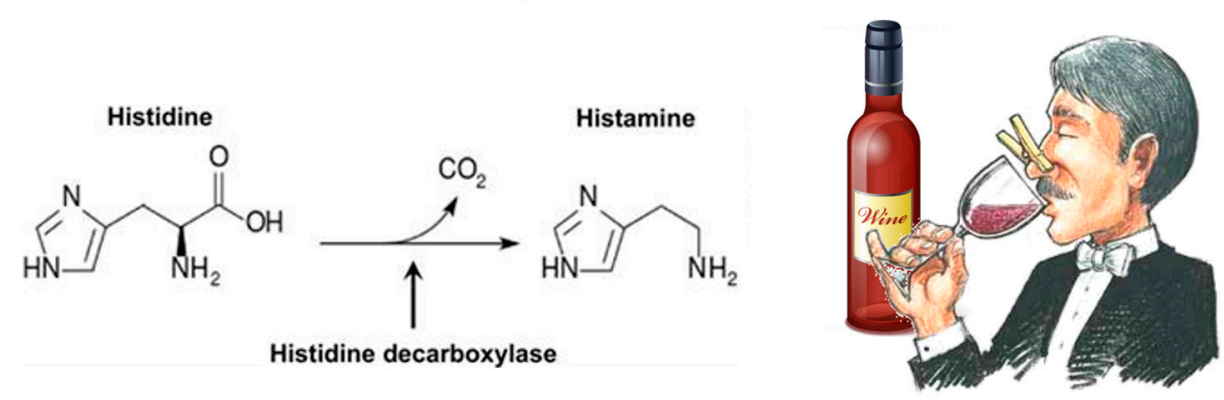

Figure 3. Biogenic amines (BAs) in wine that, besides being a healthy treat, negatively affect the aromatic quality of wines owing to their unpleasant smells (A). The decarboxylase enzyme transforms amino acid into a biogenic amine by removing its carboxyl group. The example presented is the formation of histamine (B).

The intake of high amounts of dietary BA can lead to several disorders, from minor symptoms resembling allergic reactions to death in severe cases of histaminosis or tyraminosis [20]. Moreover, the synergistic effect of inhibitors of the amino oxidases, such as some drugs, putrescine, and alcohol, lead them to act as histamine enhancers [9]. Humans' high sensitivity toward biogenic amines ingested with the diet depends on insufficient amino oxidase activity caused by drugs, genetic predisposition (histamine intolerance), gastrointestinal disease, inhibition by alcohol, acetaldehyde, and other amines like putrescine and cadaverine $[61,62]$.

Arginine and histidine are the most abundant amino acids in grapes. Consequently, histamine production in wines is a huge concern, as its toxicity is amplified by the alcohol and high levels of putrescine [63]. Besides, high levels of putrescine and cadaverine negatively affect the aromatic quality of wines owing to their unpleasant smells [63].

Some factors of agronomic practice as well as of the winemaking process can cause discrete levels of biogenic amines in the wine; that is, the fertilization of the soil (nitrogen level), the poor 
state of health of the grapes and presence of molds, non-regular lowering of the $\mathrm{pH}$ of the must and development of some non-Saccharomyces yeasts, and the activity of lactic acid bacteria responsible for malolactic fermentation (MLF) [64]. As MLF especially occurs in red wines, higher BA amounts are usually found in red wine than in rosé, white, or sparkling wines [65]. O. oeni is the main lactic acid bacteria (LAB) species carrying out the MLF, and its capability to produce histamine has been reported [62].

Yildirim et al. [66] compared organic and conventional Turkish wines from several grape varieties (Cabernet Sauvignon, Carignan, Colombard, Merlot, and Semillon) for their BA content. The highest average values were found in putrescine $(5.55 \mathrm{mg} / \mathrm{L})$, ethylamine $(0.825 \mathrm{mg} / \mathrm{L})$, and histamine $(0.628 \mathrm{mg} / \mathrm{L})$ in organic wines, and putrescine $(3.68 \mathrm{mg} / \mathrm{L})$, histamine $(1.14 \mathrm{mg} / \mathrm{L})$, and agmatine $(0.662 \mathrm{mg} / \mathrm{L})$ in non-organic wines. No $\beta$-phenylethylamine was detected. Putrescine was more predominant in organic wines than in non-organic wines $(p=0.008)$. Changes of BAs were previously studied by Garcia-Marino et al. [67] during the winemaking process of red wine, including an organic wine. Even though organic foods were popular in consumers, organic wines produced higher levels of BAs than conventional wines. This may be related to the fact that, in organic wines, MLF normally occurs spontaneously; moreover, in this kind of wine, low levels of $\mathrm{SO}_{2}$ are added owing to the legal restrictions [62].

The effect of organic or conventional agriculture on the BA content of wines was also evaluated by Tassoni et al. [68]. The authors analyzed the BA content in Lambrusco (red) and Albana (white) wines, and they compared conventional, organic, and biodynamic agricultural and oenological practices. In all the samples, putrescine was the most abundant polyamine, but its content was lower in biodynamic wines than in conventional wines. Samples from Albana organic wines and Lambrusco biodynamic wines contained the highest BA amounts, with histamine and tryptamine being the most abundant amines in both wines. Moreover, in Lambrusco, spermidine was present in organic and biodynamic samples, but it was absent in conventional samples; in Albana, this amine was present in the same amount in all of the samples.

Although biogenic amines formation during the alcoholic fermentation (AF) is considered irrelevant, during AF, yeasts consume amino acids as a nitrogen source, which plays a key role in creating aroma compounds. Caruso et al. [69] studied the BA production capability of fifty yeast strains isolated from grapes and wines. Among them, five species, Brettanomyces bruxellensis, Candida krusei, Metschnikowia pulcherrima, Kloeckera apiculate, and S. cerevisiae, were BAs producers. They also found that B. bruxellensis produced the highest levels of total BA ( $15 \mathrm{mg} / \mathrm{L})$, followed by S. cerevisiae $(12.14 \mathrm{mg} / \mathrm{L})$. Moreover, these yeast species were able to significantly produce putrescine, phenylethylamine, and ethanolamine. These results suggest that correct yeast management during winemaking is important [61].

Benito and co-workers [70] in a study aiming to evaluate the influence of Lachancea thermotolerans on low-acidity Airén grape must from the south of Spain, proving that L. thermotolerans does not produce higher levels of biogenic amines than S. cerevisiae. Moreover, the lower concentration of histidine (precursor of histamine) found during L. thermotolerans and S. cerevisiae fermentation can contribute to reducing the potential risk of histamine formation by bacterial metabolism. Other authors have also reported reductions of histamine of up to $2.2 \mathrm{mg} / \mathrm{L}$ during alcoholic fermentation with the non-Saccharomyces species Hanseniaspora vineae [71].

\section{Wines and Ethyl Carbamate Contamination}

Wine, including organic wines, possess distinct nutrients, in which a variety of microorganisms, namely yeasts and bacteria, exist. The fermentation processes may unavoidably produce toxic products because of metabolism and side reactions, including biogenic amines (BAs) and ethyl carbamate (EC). Curiously, these compounds are generated owing to the incomplete metabolism of nitrogen-containing compounds during the fermentation process [72]. EC is mainly produced by lactic acid bacteria and 
through the chemical combination of urea with ethanol during wine aging. EC has been upgraded by the IARC to a "probable human carcinogen", Group 2A [73,74].

The carcinogenicity of EC has been verified in several animal species from rats, hamsters, and monkeys [73,75]. In rodents, EC has been found to cause a dose-dependent increase in carcinomas of the liver, lungs, heart, mammary gland, ovaries, skin, and forestomach, among which hepatocellular tumors appear to linearly increase with EC concentration [74,76].

During fermentation, five metabolic pathways were identified for the formation of EC. The major precursors of the formation of EC contain a carbamyl group, and these include urea, citrulline, and carbamoyl phosphate. Furthermore, it has been shown that cyanic acid and diethylpyrocarbonate are involved in EC formation [74].

The reaction between urea and ethanol is the most common metabolic pathway of EC formation found in wine. The abundance of urea in grapes makes it the most common precursor. Moreover, during ethanol fermentation, the accumulation of urea originated from the catabolism of arginine contributes to the reaction between urea and ethanol. Additionally, urea mainly results from the metabolism of arginine by S. cerevisiae [74,77].

EC can also be formed by the reaction between citrulline and ethanol. Grape juice already contains a certain amount of citrulline, but much of this compound has its origin in the catabolism of arginine. Moreover, the generation of citrulline is assigned to the metabolism of arginine by lactic acid bacteria (LAB) via malolactic fermentation [78].

EC, in some alcoholic beverages, may also appear as a result of the reaction between cyanic acid and ethanol, and/or the reaction between carbamyl phosphate and ethanol. However, these are rare phenomena in wine [74].

The reaction between diethylpyrocarbonate and ammonia nowadays occurs less frequently, mainly in organic wines. The appearance of diethylpyrocarbonate stems from artificial additives. This compound was known to reduce contamination and spoilage by microorganisms (yeasts or bacteria). However, the use of diethylpyrocarbonate was abandoned owing to its toxicity and the undesirable side effect of EC formation [79].

To better understand the metabolic formation of EC in S. cerevisiae, transport and metabolic regulation of urea in S. cerevisiae must be studied. Intracellular urea mainly results from the degradation of arginine through catalysis by arginase (Figure 4). As a toxic and poor nitrogen source for S. cerevisiae, the generated urea is usually accumulated and exported to the nearby medium via a facilitated transport diffusion system (Figure 4, [74]). S. cerevisiae metabolizes urea in two steps. First, urea is carboxylated to form allophanate by urea carboxylase. Then, allophanate is degraded to $\mathrm{CO}_{2}$ and $\mathrm{NH}_{4}{ }^{+}$by allophanate hydrolase. The activities of urea carboxylase and allophanate hydrolase are performed by a bifunctional enzyme, urea amidolyase, encoded by the DUR1,2 genes, and silenced by nitrogen catabolic repression (NCR) [80]. The DUR3 gene encodes urea permease. Under fermentation conditions, degradation is obstructed by arginine, which is abundant in fermented sources and acts as a superior nitrogen supply compared with urea [74].

Several methods have been proposed for decreasing EC in wines: (i) the modification of raw materials (established recommendations on vineyard fertilization, cultivars, and nutrient status/additions, including avoiding excessive fertilization with urea, ammonia, and other $\mathrm{N}$-fertilizers) and the optimization of fermentation processing parameters (such as temperature, light irradiation, $\mathrm{pH}$, oxygen, and storage time); (ii) the addition of acid urease (commercial grade acid ureases are currently acquired mainly from L. fermentum) [81]; and (iii) the modification of the fermentation bacterium. All these approaches aim to reduce EC precursors [74]. However, the most common type of management in the wine industry is based on the use of a commercial urease enzyme, able to remove all of the urea that can evolve into ethyl carbamate [82]. Researchers have also focused on the immobilization of acid urease, possessing the advantages of facilitating enzyme recycling, reducing cost, and improving stability and resistance to inhibitory compounds [83]. 


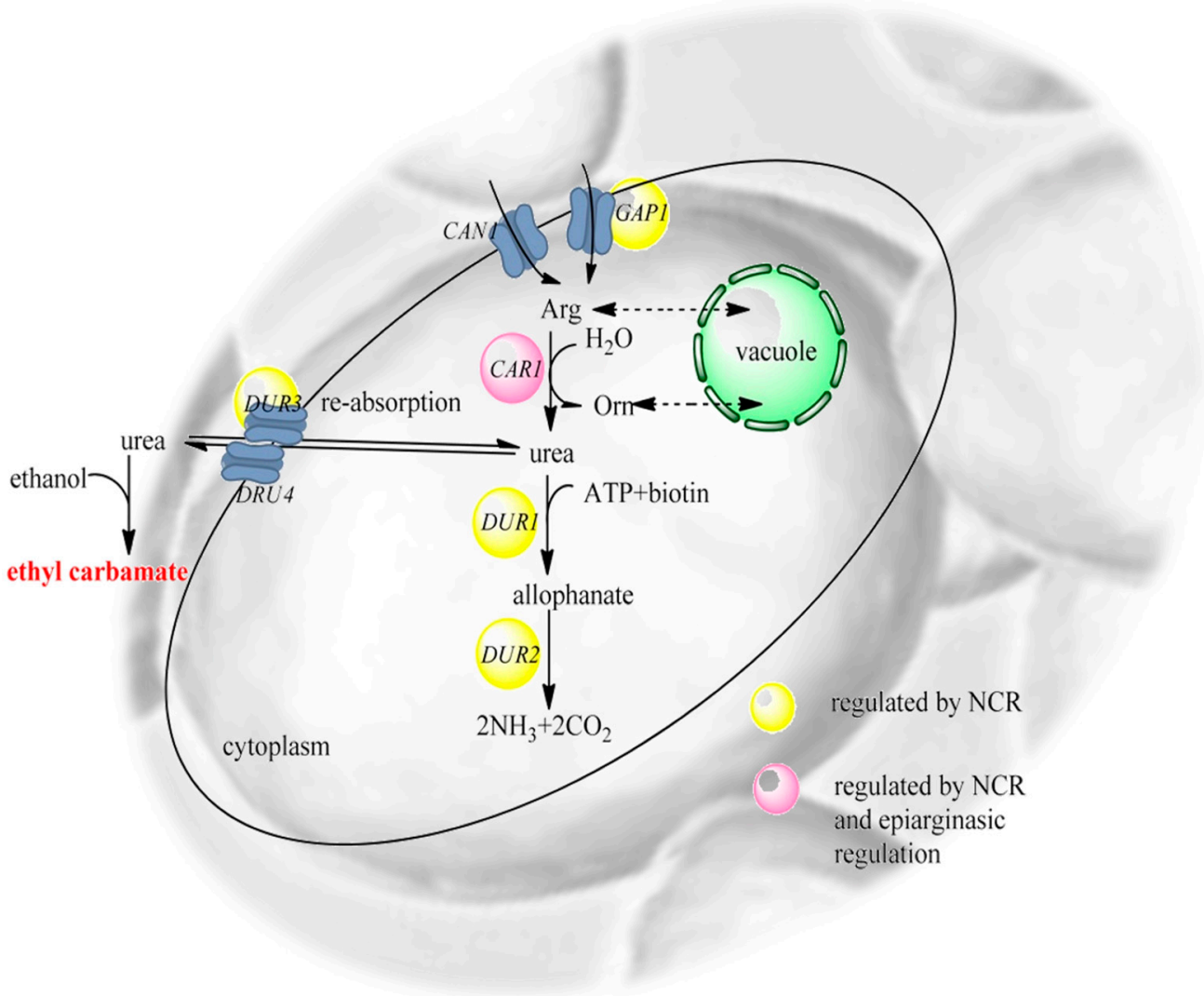

Figure 4. Schematic metabolism of urea and arginine by S. cerevisiae. Intracellular urea mainly results from the degradation of arginine through catalysis by arginase (CAR1). As a toxic and poor nitrogen source for S. cerevisiae, the generated urea is usually accumulated and exported to the surrounding medium via a facilitated diffusion system. NCR—nitrogen catabolic repression; ATP—adenosine triphosphate; CAN1—arginine transporter; GAP1—general amino acid permease [74].

However, owing to organic wine fermentation restrictions, urease cannot be used to treat this kind of wine [3]. Thus, the use of non-Saccharomyces species with urease activity allows the removal of the main ethyl carbamate precursor from wine, making it virtually impossible for ethyl carbamate to appear during wine aging [84].

Past studies of Schizosaccharomyces focused on malic acid degradation [85]. Later, the genus Schizosaccharomyces also showed the ability to reduce levels of hazardous compounds for human health, such as ochratoxin A, biogenic amines, and ethyl carbamate [86,87]. Thus, this seems to be a promising strain for EC control in organic wines.

\section{Other Benefits of the Use of Non-Saccharomyces in Organic Winemaking}

The yeast population of vineyard and grape berries surface is significant as these yeasts may contribute to the fermentative process of organic wines. It is well known that the microflora composition of grape berries surface is influenced by factors such as climate, UV radiation, nutritive limitations, and agrochemical treatments [88]. One of the objectives of organic viticulture is the use of copper- and sulfur-based molecules to protect vines as an alternative to synthetic chemical pesticides. However, these "more friendly" compounds may influence the occurrence and abundance of yeasts on the surface of grape berries. Several studies have been made, and contradictory findings have been reported. Cordero-Bueso et al. [89] found that conventional phytosanitary treatments reduced both the number and diversity of yeasts, whereas Grangeteau et al. [90] reported a lower yeast concentration and biodiversity, on grape berry surface, in organic grape samples in comparison with conventional ones. 
It is well known that indigenous yeasts can play a role in the development of distinctive terroir-related characteristics, thus creating specific traits specifically in organic wine. Moreover, after numerous studies, during the last recent years, it is believed that non-Saccharomyces are important tools for the wine fermentation process. As these yeasts are usually unable to complete alcoholic fermentation, they are mostly used in co- or sequential inoculation with S. cerevisiae $[14,91]$ in conventional or organic wines production.

Non-Saccharomyces are important to improve wine complexity and pleasantness [14,92], either alone or in co/sequential inoculation with S. cerevisiae strains. For example, Hanseniaspora vineae enhanced benzenoid compounds and phenyl ethyl acetate with an agreeable rose-like aroma [93]; Torulaspora delbrueckii increased the concentration of 3-Sulfanylhexan-1-ol (tropical fruit nuances) in the mixed fermentation with an S. cerevisiae strain [94]. Mixed fermentations with Starmerella bacillaris, Zygotorulaspora florentina, and Hanseniaspora uvarum enhanced the flavor [95], floral notes and lower perception of astringency [96], and wine organoleptic quality reducing the volatile acidity [97], respectively.

Non-Saccharomyces can also be used for controlling wild undesired microflora once many species can produce active extracellular molecules that neutralize the development of wild spoilage microorganisms. One example is the investigations focused on the biological control of the wine spoilage Brettanomyces/Dekkera yeasts [98]. In the former work, Oro and collaborators [98] demonstrated the practical application of zymocins produced by Kluyveromyces wickerhamii and Wickerhanomyces anomalus in wines contaminated by Brett, thus avoiding the use of huge amounts of sulfur dioxide. Similar studies were performed by Mehlomakulu et al. [99], finding two novel killer toxins, CpKT1 and CpKT2, produced by Candida pyralidae, active and stable under winemaking conditions; furthermore, new zymocins from $T$. delbrueckii able to control spoilage by B. bruxellensis were identified and characterized [100].

One interesting phenomenon, also recently studied, is cell-to-cell contact and quorum sensing. Quorum sensing is a mechanism in which the production of a small molecule known as an autoinducer accumulates in the extracellular environment and, on reaching a critical concentration, activates the transcription of target genes [101]. Quorum sensing was recently analyzed in S. cerevisiae, H Hanseniaspora uvarum, Torulaspora pretoriensis, Zygosaccharomyces bailii, Candida zemplinina, and Dekkera bruxellensis, and 2-phenylethanol, tryptophol, and tyrosol, produced by these non-Saccharomyces yeasts, were found to be the main molecules involved in the quorum-sensing mechanism [102].

The use of non-Saccharomyces can be a biological way to reduce the ethanol content in wines. Different mechanisms of some of these yeasts, balanced between respiration and fermentation, compared with S. cerevisiae, could be explored to reduce ethanol production through partial and controlled aeration of the grape juice. In this way, sugar is consumed via respiration rather than fermentation [103,104].

Non-Saccharomyces yeasts can also be a valuable tool for production low-sulfur wines. Owing to the restrictions imposed by the EU on additives used in organic wines, the main concern in the organic winemaking process is the risks of oxidation combined with microbial contamination and $\mathrm{H}_{2} \mathrm{~S}$ production. Although new starters 'low $\mathrm{H}_{2} \mathrm{~S}_{-} \mathrm{SO}_{2}$-acetaldehyde producers', obtained by selective breeding, are already available in the market, indigenous tailor-made yeasts are needed to imprint the wines with the specific terroir, and simultaneously, to avoid the production of compounds undesirable in organic wines [88,105]. Moreover, non-Saccharomyces are also able to reduce copper, which can appear in organic wines owing to the use of copper fungicide in organic agricultural practices. These metals in concentrations higher than $64 \mathrm{mg} / \mathrm{L}$ cause sluggish or stuck fermentation and a reduction in alcohol production [88].

\section{Final Remarks}

The growing social interest in organic wines stimulated several studies aiming at improving organic grape production and organic wine quality during the entire chain production. A change 
in consumer preference towards organic wines, perceived to be more natural, made using less or no chemical additions as compared with conventional wine, has encouraged bioprospecting for naturally occurring microorganisms, yeast, and bacteria, which can be applied in winemaking as an alternative to such additions.

Furthermore, the increasing request of organic wines determines changes in yeast microbiota and fermentation requirements, demanding starter strains, particularly non-Saccharomyces, with peculiar features, such as low production of $\mathrm{H}_{2} \mathrm{~S}, \mathrm{SO}_{2}$, and acetaldehyde; the reduction of ethanol content; the ability to reduce copper content; the bio-control of undesirable spoilage yeasts; and more importantly, the possible control of mycotoxins (like OTA), biogenic amines (BAs), and ethyl carbamate (EC), harmful compounds for human health.

In conclusion, the use of selected cultures of non-Saccharomyces wine yeasts in organic wines production, further than the enhancement of wine complexity and typicity, offers other advantages, related to wine safety and consumer's health.

Funding: FCT and COMPETE, grants numbers UIDB/00616/2020 and UIDP/00616/2020.

Acknowledgments: The author appreciates the financial support provided to the Research Unit in Vila Real (CQ-VR).

Conflicts of Interest: The author declares no conflict of interest.

\section{References}

1. IFOAM. Basic Standards for Organic Production and Processing. Bonn-Germany. 2014. Available online: http://www.ifoam.orghttps://www.ifoam.bio/sites/default/files/ifoam_norms_july_2014_t.pdf (accessed on 15 April 2020).

2. Trioli, G.; Hofmann, U. ORWINE: Code of good organic viticulture and winemaking. In ECOVIN-Federal Association of Organic Wine-Producer; Ecovin: Oppenheim, Germany, 2009.

3. IFAOM. EU Rules for Organic Wine Production: Background, Evaluation, and Further Sector Development. 2013. Available online: https://orgprints.org/29867/1/ifoameu_reg_wine_dossier_201307.pdf (accessed on 17 April 2020).

4. Commission Implementing Regulation (EU) No 203/2012 of 8 March 2012 Amending Regulation (EC) No 889/2008 Laying Down Detailed Rules for the Implementation of Council Regulation (EC) No 834/2007, as Regards Detailed Rules on Organic Wine. OJ L 71. 9 March 2012, pp. 42-47. Available online: https://eur-lex.europa.eu/legal-content/EN/TXT/?uri=celex\%3A32012R0203 (accessed on 10 May 2020).

5. Schäufele, I.; Hamm, U. Consumers' perceptions, preferences, and willingness-to-pay for wine with sustainability characteristics: A review. J. Clean. Prod. 2017, 147, 379-394. [CrossRef]

6. Cravero, M.C. Organic, and biodynamic wines quality and characteristics: A review. Food Chem. 2019, 295, 334-340. [CrossRef] [PubMed]

7. DIVA. Overview of the Organic Wine Market. 2007. Available online: https://divawine.com/overvieworganic-market/ (accessed on 7 May 2020).

8. Tofalo, R.; Schirone, M.; Telera, G.C.; Manetta, A.C.; Corsetti, A.; Suzzi, G. Influence of organic viticulture on non-Saccharomyces wine yeast populations. Ann. Microbiol. 2011, 61, 57-66. [CrossRef]

9. Russo, P.; Capozzi, V.; Spano, G.; Corbo, M.R.; Sinigaglia, M.; Antonio, B. Metabolites of Microbial Origin with an Impact on Health: Ochratoxin A and Biogenic Amines. Front. Microbiol. 2016, 7, 482. [CrossRef]

10. Ciani, M.; Comitini, F. Non-Saccharomyces wine yeasts have a promising role in biotechnological approaches to winemaking. Ann. Microbiol. 2011, 61, 25-32. [CrossRef]

11. Jolly, N.P.; Varela, C.; Pretorius, I.S. Not your ordinary yeast: Non-Saccharomyces yeasts in wine production uncovered. FEMS Yeast Res. 2014, 14, 215-237. [CrossRef]

12. Maurizio, C.; Francesca, C.; Ilaria, M.; Paola, D. Controlled mixed culture fermentation: A new perspective on the use of non-Saccharomyces yeasts in winemaking. FEMS Yeast Res. 2010, 10, 123-133. [CrossRef]

13. Vilela, A. The Importance of Yeasts on Fermentation Quality and Human Health-Promoting Compounds. Fermentation 2019, 5, 46. [CrossRef] 
14. Vilela, A. Modulating Wine Pleasantness Throughout Wine-Yeast Co-Inoculation or Sequential Inoculation. Fermentation 2020, 6, 22. [CrossRef]

15. Walker, R. Risk assessment of ochratoxin: Current views of the European Scientific Committee on Food, the JECFA and the Codex Committee on Food Additives and Contaminants. Adv. Exp. Med. Biol. 2002, 504, 249-255. [CrossRef]

16. Ji, C.; Fan, Y.; Zhao, L. Review on biological degradation of mycotoxins. Anim. Nutr. 2016, 2, 127-133. [CrossRef]

17. Barreira, M.J.; Alvito, P.C.; Almeida, C.M. Occurrence of patulin in apple-based foods in Portugal. Food Chem. 2010, 121, 653-658. [CrossRef]

18. Peraica, M.; Radic, B.; Lucicć, P.; Pavlovic, M. Toxic effects of mycotoxins in humans. Int. J. Public Health 1999, 77, 754-766.

19. Ferenczi, S.; Cserháti, M.; Krifaton, C.; Szoboszlay, S.; Kukolya, J.; Szőke, Z.; Kovács, K.J. A New Ochratoxin A Biodegradation Strategy Using Cupriavidus basilensis Őr16 Strain. PLoS ONE 2014, 9, e109817. [CrossRef] [PubMed]

20. Spano, G.; Russo, P.; Lonvaud-Funel, A.; Lucas, P.; Alexandre, H.; Grandvalet, C.; Rattray, F. Biogenic amines in fermented foods. Eur. J. Clin. Nutr. 2010, 64, 95-100. [CrossRef]

21. Petruzzi, L.; Sinigaglia, M.; Corbo, M.R.; Campaniello, D.; Speranza, B.; Bevilacqua, A. Decontamination of Ochratoxin A by yeasts: Possible approaches and factor leading to toxin removal in wine. Appl. Microbiol. Biotechnol. 2014, 98, 6555-6567. [CrossRef]

22. Battilani, P.; Giorni, P.; Bertuzzi, T.; Formenti, S.; Pietri, A. Black Aspergilli and Ochratoxin A in grapes in Italy. Int. J. Food Microbiol. 2006, 111, S53-S60. [CrossRef]

23. Bellver Soto, J.; Fernández-Franzón, M.; Ruiz, M.J.; García, A.J. Presence of Ochratoxin A (OTA) mycotoxin in alcoholic drinks from southern European countries: Wine and beer. J. Agric. Food Chem. 2014, 62, 7643-7651. [CrossRef]

24. IARC. Mycotoxins and Human Health (Chapter 6). 2020; pp. 87-104. Available online: file://C:/Users/avimo/ Downloads/IARC_SP158_Chapter\%206.pdf (accessed on 17 April 2020).

25. EFSA (European Food Safety Authority). Opinion of the scientific panel on contaminants in the food chain on a request. Commission related to Ochratoxin A in food. EFSA J. 2006, 365, 1-56.

26. Quintela, S.; Villarán, M.C.; Armentia, I.L.; Elejalde, E. Ochratoxin A removal in wine: A review. Food Control 2013, 30, 439-445. [CrossRef]

27. Pitout, M.J. The hydrolysis of ochratoxin A by some proteolytic enzymes. Biochem. Pharmacol. 1969, 18, 485-491. [CrossRef]

28. Abrunhosa, L.; Inês, A.; Rodrigues, A.I.; Guimarães, A.; Pereira, V.L.; Paropt, P.; Venâncio, A. Biodegradation of Ochratoxin A by Pediococcus parvulus isolated from Douro wines. Int. J. Food Microbiol. 2014, 188, 45-52. [CrossRef] [PubMed]

29. De Bellis, P.; Tristezza, M.; Haidukowski, M.; Fanelli, F.; Sisto, A.; Mulè, G.; Grieco, F. Biodegradation of Ochratoxin A by Bacterial Strains Isolated from Vineyard Soils. Toxins (Basel) 2015, 7, 5079-5093. [CrossRef] [PubMed]

30. Friman, H.; Schechter, A.; Ioffe, Y.; Nitzan, Y.; Cahan, R. Electricity formation in a microbial fuel cell. Microb. Biotechnol. 2013, 6, 425-434. [CrossRef]

31. Caridi, A.; Cufari, A.; Lovino, R.; Palumbo, R.; Tedesco, I. Influence of yeast on polyphenol composition of wine. Food Technol. Biotechnol. 2004, 42, 37-40.

32. Petruzzi, L.; Baiano, A.; De Gianni, A.; Sinigaglia, M.; Corbo, M.R.; Bevilacqua, A. Differential Adsorption of Ochratoxin A and Anthocyanins by Inactivated Yeasts and Yeast Cell Walls during Simulation of Wine Aging. Toxins (Basel) 2015, 7, 4350-4365. [CrossRef]

33. Bevilacqua, A.; Petruzzi, L.; Corbo, M.R.; Baiano, A.; Garofalo, C.; Sinigaglia, M. Ochratoxin A released back into the medium by Saccharomyces cerevisiae as a function of the strain, washing medium, and fermentative conditions. J. Sci. Food Agric. 2014, 94, 3291-3295. [CrossRef]

34. Mazauric, J.P.; Salmon, J.M. Interactions between yeast lees and wine polyphenols during simulation of wine aging: II. Analysis of desorbed polyphenol compounds from yeast lees. J. Agric. Food Chem. 2006, 54, 3876-3881. [CrossRef]

35. Palacios, S.; Vasserot, Y.; Maujean, A. Evidence for sulfur volatile products adsorption by yeast lees. Am. J. Enol. Vitic. 1997, 48, 525-526. 
36. Alexandre, H.; Lubbers, S.; Charpentier, C. Interactions between toxic fatty acids for yeasts and colloids, cellulose and yeast ghost using the equilibrium dialysis method in a model wine system. Food Biotechnol. 1997, 11, 89-99. [CrossRef]

37. Navarro, S.; Barba, A.; Oliva, J.; Navarro, G.; Pardo, F. Evolution of residual levels of six pesticides during elaboration of red wines. Effect of wine-making procedures in their disappearance. J. Agric. Food Chem. 1999, 47, 264-270. [CrossRef]

38. Pradelles, R.; Chassagne, D.; Vichi, S.; Gougeon, R.; Alexandre, H. (-) Geosmin sorption by enological yeasts in model wine and FTIR spectroscopy characterization of the sorbent. Food Chem. 2010, 120, 531-538. [CrossRef]

39. Palomero, F.; Ntanos, K.; Morata, A.; Benito, S.; Suárez-Lepe, J.A. Reduction of wine 4-ethylphenol concentration using lyophilized yeast as a bioadsorbent: Influence on anthocyanin content and chromatic variables. Eur. Food Res. Technol. 2011, 232, 971-977. [CrossRef]

40. Anwar, M.I.; Muhammad, F.; Awais, M.M.; Akhtar, M. A review of $\beta$-glucans as a growth promoter and antibiotic alternative against enteric pathogens in poultry. World's Poult. Sci. J. 2017, 73, 651-661. [CrossRef]

41. Huwig, A.; Freimund, S.; Käppeli, O.; Dutler, H. Mycotoxin detoxication of animal feed by different adsorbents. Toxicol Lett. 2001, 122, 179-188. [CrossRef]

42. Domizio, P.; Liu, Y.; Bisson, L.F.; Barile, D. Cell wall polysaccharides released during the alcoholic fermentation by Schizosaccharomyces pombe and S. japonicus: Quantification and characterization. Food Microbiol. 2017, 61, 136-149. [CrossRef]

43. Marx, H.; Sauer, M.; Resina, D.; Vai, M.; Porro, D.; Valero, F.; Ferrer, P.; Mattanovich, D. Cloning, disruption and protein secretory phenotype of the GAS1 homologue of Pichia pastoris. FEMS Microbiol. Lett. 2006, 264, 40-47. [CrossRef]

44. Jigami, Y.; Odani, T. Mannosylphosphate transfer to yeast mannan. Molecular and Cell Biology of Lipids. Biochim. Biophys. Acta 1999, 1426, 335-345. [CrossRef]

45. Esti, M.; Benucci, I.; Liburdi, K.; Acciaro, G. Monitoring of ochratoxin A fate during alcoholic fermentation of wine must. Food Control. 2012, 27, 53-56. [CrossRef]

46. Luo, Y.; Liu, X.; Yuan, L.; Li, J. Complicated interactions between bio-adsorbents and mycotoxins during mycotoxin adsorption: Current research and future prospects. Trends Food Sci. Technol. 2020, 96, 127-134. [CrossRef]

47. Bejaoui, H.; Mathieu, F.; Taillandier, P.; Lebrihi, A. Ochratoxin A removal in synthetic and natural grape juices by selected oenological Saccharomyces strains. J. Appl. Microbiol. 2004, 97, 1038-1044. [CrossRef] [PubMed]

48. Ringot, D.; Lerzy, B.; Bonhoure, J.P.; Auclair, E.; Oriol, E.; Larondelle, Y. Effect of temperature on in vitro ochratoxin A biosorption onto yeast cell wall derivatives. Proc. Biochem. 2005, 40, 3008-3016. [CrossRef]

49. Caridi, A. New perspectives in safety and quality enhancement of wine through selection of yeasts based on the parietal adsorption activity. Int. J. Food Microbiol. 2007, 120, 167-172. [CrossRef]

50. Piotrowska, M.; Masek, A. Saccharomyces Cerevisiae Cell Wall Components as Tools for Ochratoxin A Decontamination. Toxins 2015, 7, 1151-1162. [CrossRef] [PubMed]

51. Farbo, M.G.; Urgeghe, P.P.; Fiori, S.; Marceddu, S.; Jaoua, S.; Migheli, Q. Adsorption of Ochratoxin A from grape juice by yeast cells immobilised in calcium alginate beads. Int. J. Food Microbiol. 2016, 217, $29-34$. [CrossRef] [PubMed]

52. Pfliegler, W.P.; Pusztahelyi, T.; Pócsi, I. Mycotoxins-prevention and decontamination by yeasts. J. Basic Microbiol. 2015, 55, 805-818. [CrossRef]

53. Cecchini, F.; Morassut, M.; Saiz, J.C.; Moruno, E.G. Anthocyanins enhance yeast's adsorption of Ochratoxin A during the alcoholic fermentation. Eur. Food Res. Technol. 2019, 245, 309-314. [CrossRef]

54. Luo, Y.; Wang, Z.L.; Yuan, Y.H.; Zhou, Z.K.; Yue, T.L. Patulin adsorption of a superior microorganism strain with low flavor-affection of kiwi fruit juice. World Mycotoxin J. 2016, 9, 195-203. [CrossRef]

55. Nunez, Y.P.; Pueyo, E.; Carrascosa, A.V.; Martínez-Rodríguez, A.J. Effects of Aging and Heat Treatment on Whole Yeast Cells and Yeast Cell Walls and on Adsorption of Ochratoxin A in a Wine Model System. J. Food Prot. 2008, 71, 1496-1499. [CrossRef]

56. Armando, M.R.; Pizzolitto, R.P.; Dogi, C.A.; Cristofolini, A.; Merkis, C.; Poloni, V.; Cavaglieri, L.R. Adsorption of ochratoxin A and zearalenone by potential probiotic Saccharomyces cerevisiae strains and its relation with cell wall thickness. J. Appl. Microbiol. 2012, 113, 256-264. [CrossRef] 
57. Luo, Y.; Wang, J.G.; Liu, B.; Wang, Z.L.; Yuan, Y.H.; Yue, T.L. Effect of yeast cell morphology, cell wall physical structure and chemical composition on patulin adsorption. PLoS ONE 2015, 21, e0136045. [CrossRef] [PubMed]

58. Wolken, W.A.M.; Lucas, P.M.; Lonvaud-Funel, A.; Lolkema, J.S. The mechanism of the tyrosine transporter TyrP supports a proton motive tyrosine decarboxylation pathway in Lactobacillus brevis. J. Bacteriol. 2006, 188, 2198-2206. [CrossRef] [PubMed]

59. Smit, A.Y.; du Toit, W.J.; du Toit, M. Biogenic amines in wine: Understanding the headache. South Afr. J. Enol. Vitic. 2008, 29, 109-127. [CrossRef]

60. Cappello, M.S.; Zapparoli, G.; Logrieco, A.; Bartowsky, E.J. Linking wine lactic acid bacteria diversity with wine aroma and flavour. Review article. Int. J. Food Microbiol. 2017, 243, 16-27. [CrossRef] [PubMed]

61. Guo, Y.-Y.; Yang, Y.-P.; Peng, Q.; Han, Y. Biogenic amines in wine: A review. Int. J. Food Sci. Technol. 2015, 50, 1523-1532. [CrossRef]

62. Martuscelli, M.; Mastrocola, D. Biogenic Amines: A Claim for Wines, Biogenic Amines, Charalampos Proestos; IntechOpen: London, UK, 2018. [CrossRef]

63. Beneduce, L.; Romano, A.; Capozzi, V.; Lucas, P.; Barnavon, L.; Bach, B.; Spano, G. Biogenic amines in regional wines. Ann. Microbiol. 2010, 60, 573-578. [CrossRef]

64. Ancín-Azpilicueta, C.; González-Marco, A.; Jiménez-Moreno, N. Current knowledge about the presence of amines in wine. Crit. Rev. Food Sci. Nutr. 2008, 48, 257-275. [CrossRef]

65. Tassoni, A.; Tango, N.; Ferri, M. Comparison of biogenic amine and polyphenol profiles of grape berries and wines obtained following conventional, organic and biodynamic agricultural and oenological practices. Food Chem. 2013, 139, 405-413. [CrossRef]

66. Yildirim, H.K.; Üren, A.; Yücel, U. Evaluation of biogenic amines in organic and non-organic wines by HPLC OPA derivatization. Food Technol. Biotechnol. 2007, 45, 62-68.

67. Garcia-Marino, M.; Trigueros, Á.; Escribano-Bailón, T. Influence of oenological practices on the formation of biogenic amines in quality red wines. J. Food Comp. Anal. 2010, 23, 455-462. [CrossRef]

68. Tassoni, A.; Tango, N.; Ferri, M. Polyphenol and Biogenic Amine Profiles of Albana and Lambrusco Grape Berries and Wines Obtained Following Different Agricultural and Oenological Practices. Food Nutr. Sci. 2014, 5, 8-16. [CrossRef]

69. Caruso, M.; Fiore, C.; Contursi, M.; Salzano, G.; Paparella, A.; Romano, P. Formation of biogenic amines as criteria for the selection of wine yeasts. World J. Microbiol. Biotechnol. 2002, 18, 159-163. [CrossRef]

70. Benito, Á.; Calderón, F.; Palomero, F.; Benito, S. Quality and Composition of Airén Wines Fermented by Sequential Inoculation of Lachancea thermotolerans and Saccharomyces cerevisiae. Food Technol. Biotechnol. 2016, 54, 135-144. [CrossRef] [PubMed]

71. Medina, K.; Boido, E.; Fariña, L.; Gioia, O.; Gomez, M.E.; Barquet, M.; Gaggero, C.; Dellacassa, E.; Carrau, F. Increased flavour diversity of Chardonnay wines by spontaneous fermentation and co-fermentation with Hanseniaspora vineae. Food Chem. 2013, 141, 2513-2521. [CrossRef]

72. Thibon, C.; Marullo, P.; Claisse, O.; Cullin, C.; Dubourdieu, D.; Tominaga, T. Nitrogen catabolic repression controls the release of volatile thiols by Saccharomyces cerevisiae during wine fermentation. Fems Yeast Res. 2008, 8, 1076-1086. [CrossRef]

73. Thorgeirsson, U.P.; Dalgard, D.W.; Reeves, J.; Adamson, R.H. Tumor incidence in a chemical carcinogenesis study of nonhuman primates. Regul. Toxicol. Pharm. 1994, 19, 130-151. [CrossRef]

74. Jiao, Z.; Dong, Y.; Chen, Q. Ethyl Carbamate in Fermented Beverages: Presence, Analytical Chemistry, Formation Mechanism, and Mitigation Proposals. Compr. Rev. Food Sci. Food Saf. 2014, 13, 611-626. [CrossRef]

75. Salmon, A.G.; Zeise, L. Risks of Carcinogenesis from Urethane Exposure; CRC Press: Boca Raton, FL, USA, 1991; p. 115.

76. Beland, F.A.; Benson, R.W.; Mellick, P.W.; Kovatch, R.M.; Roberts, D.W.; Fang, J.-L.; Doerge, D.R. Effect of ethanol on the tumorigenicity of urethane (ethyl carbamate) in B6C3F1 mice. Food Chem. Toxicol. 2005, 43, 1-19. [CrossRef]

77. Dahabieh, M.; Husnik, J.; Van Vuuren, H. Functional enhancement of sake yeast strains to minimize the production of ethyl carbamate in sake wine. J. Appl. Microbiol. 2010, 109, 963-973. [CrossRef]

78. Arena, M.; Saguir, F.; Manca de Nadra, M. Arginine, citrulline and ornithine metabolism by lactic acid bacteria from wine. Int. J. Food Microbiol. 1999, 52, 155-161. [CrossRef] 
79. Polychroniadou, E.; Kanellaki, M.; Iconomopoulou, M.; Koutinas, A.; Marchant, R.; Banat, I. Grape and apple wines volatile fermentation products and possible relation to spoilage. Bioresour. Technol. 2003, 87, 337-339. [CrossRef]

80. Zhao, X.; Zou, H.; Fu, J.; Chen, J.; Zhou, J.; Du, G. Nitrogen regulation involved in the accumulation of urea in Saccharomyces cerevisiae. Yeast 2013, 30, 437-447. [CrossRef] [PubMed]

81. Fidaleo, M.; Esti, M.; Moresi, M. Assessment of urea degradation rate in model wine solutions by acid urease from Lactobacillus fermentum. J. Agric. Food Chem. 2006, 54, 6226-6235. [CrossRef] [PubMed]

82. Benito, S. The Management of Compounds that Influence Human Health in Modern Winemaking from an HACCP Point of View. Fermentation 2019, 5, 33. [CrossRef]

83. Andrich, L.; Esti, M.; Moresi, M. Urea removal in model wine solutions by immobilized acid urease in a stirred bioreactor. Chem. Eng. Trans. 2009, 17, 915-920. [CrossRef]

84. Pflaum, T.; Hausler, T.; Baumung, C.; Ackermann, S.; Kuballa, T.; Rehm, J.; Lachenmeier, D.W. Carcinogenic compounds in alcoholic beverages: An update. Arch. Toxicol. 2016, 90, 2349-2367. [CrossRef] [PubMed]

85. Silva, S.; Ramón-Portugal, F.; Andrade, P.; Abreu, S.; de Fatima, T.M.; Strehaiano, P. Malic acid consumption by dry immobilized cells of Schizosaccharomyces pombe. Am. J. Enol. Vitic. 2003, 54, 50-55.

86. Cecchini, F.; Morassut, M.; Moruno, E.G.; Di Stefano, R. Influence of yeast strain on ochratoxin A content during fermentation of white and red must. Food Microbiol. 2006, 23, 411-417. [CrossRef]

87. Benito, Á.; Calderón, F.; Benito, S. Combined use of S. pombe and L. thermotolerans in winemaking. Beneficial effects determined through the study of wines' analytical characteristics. Molecules 2016, 21, 1744. [CrossRef]

88. Comitini, F.; Capece, A.; Ciani, M.; Romano, P. New insights on the use of wine yeasts. Curr. Opin. Food Sci. 2017, 13, 44-49. [CrossRef]

89. Cordero-Bueso, G.; Arroyo, T.; Serrano, A.; Tello, J.; Aporta, I.; Vélez, M.D.; Valero, E. Influence of the farming system and vine variety on yeast communities associated with grape berries. Int. J. Food Microbiol. 2011, 145, 132-139. [CrossRef] [PubMed]

90. Grangeteau, C.; Gerhards, D.; von Wallbrunn, C.; Alexandre, N.; Rousseaux, S.; Guilloux-Benatier, M. Persistence of two non-Saccharomyces yeasts (Hanseniaspora and Starmerella) in the cellar. Front. Microbiol. 2016, 7, 11. [CrossRef]

91. Comitini, F.; Gobbi, M.; Domizio, P.; Romani, C.; Lencioni, L.; Mannazzu, I.; Ciani, M. Selected non-Saccharomyces wine yeasts in controlled multistarter fermentations with Saccharomyces cerevisiae. Food Microbiol. 2011, 28, 873-882. [CrossRef] [PubMed]

92. Morata, A.; Benito, S.; Loira, I.; Palomero, F.; González, M.C.; Suárez-Lepe, J.A. Formation of pyranoanthocyanins by Schizosaccharomyces pombe during the fermentation of red must. Int. J. Food Microbiol. 2012, 159, 47-53. [CrossRef]

93. Lleixà, J.; Martín, V.; Portillo, M.C.; Carrau, F.; Beltran, G.; Mas, A. Comparison of fermentation and wines produced by inoculation of Hanseniaspora vineae and Saccharomyces cerevisiae. Front. Microbiol. 2016, 7, 338. [CrossRef] [PubMed]

94. Renault, P.; Coulon, J.; Moine, V.; Thibon, C.; Bely, M. Enhanced 3-sulfanylhexan-1-ol production in sequential mixed fermentation with Torulaspora delbrueckii/Saccharomyces cerevisiae reveals a situation of synergistic interaction between two industrial strains. Front. Microbiol. 2016, 7, 22. [CrossRef]

95. Englezos, V.; Torchio, F.; Cravero, F.; Marengo, F.; Giacosa, S.; Gerbi, V.; Rantsiou, K.; Rolle, L.; Cocolin, L. Aroma profile and composition of Barbera wines obtained by mixed fermentations of Starmerella bacillaris (synonym Candida zemplinina) and Saccharomyces cerevisiae. LWT_Food Sci. Technol. 2016, 73, 567-575. [CrossRef]

96. Lencioni, L.; Romani, C.; Gobbi, M.; Comitini, F.; Ciani, M.; Domizio, P. Controlled mixed fermentation at winery scale using Zygotorulaspora florentina and Saccharomyces cerevisiae. Int. J. Food Microbiol. 2016, 234, 36-44. [CrossRef]

97. Tristezza, M.; Tufariello, M.; Capozzi, V.; Spano, G.; Mita, G.; Grieco, F. The oenological potential of Hanseniaspora uvarum in simultaneous and sequential co-fermentation with Saccharomyces cerevisiae for industrial wine production. Front. Microbiol. 2016, 7, 670. [CrossRef]

98. Oro, L.; Ciani, M.; Bizzaro, D.; Comitini, F. Evaluation of damage induced by Kwkt and Pikt zymocins against Brettanomyces/Dekkera spoilage yeast, as compared to sulphur dioxide. J. Appl. Microbiol. 2016, 121, 207-214. [CrossRef] 
99. Mehlomakulu, N.N.; Setati, M.E.; Divol, B. Characterization of novel killer toxins secreted by wine- related non-Saccharomyces yeasts and their action on Brettanomyces spp. Int. J. Food Microbiol. 2014, 8, 83-91. [CrossRef] [PubMed]

100. Villalba, M.L.; Susana- Sáez, J.; Del Monaco, S.; Lopes, C.A.; Sangorrín, M.P. TdKT, a new killer toxin produced by Torulaspora delbrueckii effective against wine spoilage yeasts. Int. J. Food Microbiol. 2016, 217, 94-100. [CrossRef] [PubMed]

101. Zupan, J.; Avbelj, M.; Butinar, B.; Kosel, J.; Šergan, M.; Raspor, P. Monitoring of quorum-sensing molecules during minifermentation studies in wine yeast. J. Agric. Food Chem. 2013, 61, 2496-2505. [CrossRef] [PubMed]

102. Avbelj, M.; Zupan, J.; Raspor, P. Quorum-sensing in yeast and its potential in wine making. Appl. Microbiol. Biotechnol. 2016, 100, 7841-7852. [CrossRef]

103. Contreras, A.; Hidalgo, C.; Schmidt, S.; Henschke, P.A.; Curtin, C.; Varela, C. The application of nonSaccharomyces yeast in fermentations with limited aeration as a strategy for the production of wine with reduced alcohol content. Int. J. Food Microbiol. 2015, 205, 7-15. [CrossRef]

104. Ciani, M.; Morales, P.; Comitini, F.; Tronchoni, J.; Canonico, L.; Curiel, J.A.; Oro, L.; Rodrigues, A.J.; Gonzalez, R. Non-conventional yeast species for lowering ethanol content of wines. Front. Microbiol. 2016, 7, 642. [CrossRef]

105. Balboa-Lagunero, T.; Arroyo, T.; Cabellos, J.M.; Aznar, M. Yeast selection as a tool for reducing key oxidation notes in organic wines. Food Res. Int. 2013, 53, 252-259. [CrossRef]

(C) 2020 by the author. Licensee MDPI, Basel, Switzerland. This article is an open access article distributed under the terms and conditions of the Creative Commons Attribution (CC BY) license (http://creativecommons.org/licenses/by/4.0/). 